\title{
Heavy Metal Pollution in Soil and Water in Some Selected Towns in Dunkwa-on-Offin District in the Central Region of Ghana as a Result of Small Scale Gold Mining
}

\author{
Jerome D. A. Kpan ${ }^{1,2 *}$, Boadu Kwesi Opoku², Anukwah Gloria ${ }^{2}$ \\ ${ }^{1}$ College of Optical-Electrical and Computer Engineering, University of Shanghai for Science and Technology, \\ Shanghai, China \\ ${ }^{2}$ Department of Chemistry, University of Cape Coast, Cape Coast, Ghana \\ Email: ${ }^{*}$ kpanomage5@gmail.com
}

Received 17 February 2014; revised 24 March 2014; accepted 5 April 2014

Copyright $@ 2014$ by authors and Scientific Research Publishing Inc.

This work is licensed under the Creative Commons Attribution International License (CC BY). http://creativecommons.org/licenses/by/4.0/

(c) $\underset{\mathrm{EY}}{\text { (i) }}$ Open Access

\section{Abstract}

Illegal small scale gold mining popularly called "Galamsey" in our local communities is on the increase. This has led to concerns about the level of environmental pollution resulting from these mining activities. This work was conducted to determine the level of heavy metal contamination in the environment due to the activities of the small scale miners. This paper discusses the concentrations of some selected heavy metals $-\mathrm{Hg}$, $\mathrm{Pb}$, and $\mathrm{Cu}$ which were measured in 14 sampling sites in Dunkwa-on-Offin in the Central Region of Ghana, known for these activities. The heavy metal concentrations have been investigated for soil and water samples in the selected towns and compared with the relevant guidelines of the Environmental Protection Agency. The concentration of heavy metals was measured by using AAS. In most locations, the concentration for the investigated heavy metals far exceeded the concentration admitted by the guidelines. The mean concentration of Lead was $95.13 \mathrm{mg} / \mathrm{Kg}$ for soil and $190.27 \mathrm{mg} / \mathrm{L}$ in water; Copper was $63.26 \mathrm{mg} / \mathrm{Kg}$ in soil and $75.92 \mathrm{mg} / \mathrm{L}$ in water while Mercury was $140.87 \mathrm{ug} / \mathrm{Kg}$ in soil and $211.31 \mathrm{mg} / \mathrm{L}$ in water. The mean recorded concentrations in the sensitive areas exceeded greatly. Hence the levels of heavy metal contamination have spread beyond control.

\section{Keywords}

Small-Scale Gold Mining, Mercury Pollution, Heavy Metal, Dunkwa-on-Offin, Ghana

\footnotetext{
${ }^{*}$ Corresponding author.
}

How to cite this paper: Kpan, J.D.A., et al. (2014) Heavy Metal Pollution in Soil and Water in Some Selected Towns in Dunkwa-on-Offin District in the Central Region of Ghana as a Result of Small Scale Gold Mining. Journal of Agricultural Chemistry and Environment, 3, 40-47. http://dx.doi.org/10.4236/jacen.2014.32006 


\section{Introduction}

Small scale gold mining, popularly called "galamsy” in Ghana and other developing countries, is seen as a source of subsistence and a determinant of the environmental degradation [1]. In Ghana, small scale gold mining is set to be responsible for about $5 \%$ of the annual gold production. However, this gold mining of late has become unpopular as it is seen as the source of significant heavy metal contamination of the environment [2]. Some of the impacts associated with this small scale gold mining include the destruction of vegetation, land degradation and the pollution of water bodies. The rate at which mercury is discharged into the environment and water bodies is very alarming [3]-[5]. In small scale gold mining, simple tools are used in the recovery of gold from the land. Pits are dug haphazardly and these remain uncovered long after their operations. It's reported that in a prospecting work in a field, a pit that was dug revealed the presence of mercury in the soil [6]. Tetteh, et al. (2010) [7] reported high levels of mercury and zinc content in the top soil of towns in Wassa West. The levels of the concentration, however, decreased with distance from the main mining centers and extended beyond most probably due to aerial dispersion of the metal from mining areas.

Amalgamation is the preferred method used for the extraction of this free gold from its ores. The gold amalgam is usually roasted to release the mercury and to concentrate the gold. The excess mercury which is discarded into the environment finds its way into the water bodies [8]. Methylmercury in water and mercury oxides in the air as a result of the gold amalgam finds its way in humans through the food chain as in ingestion of mercury contaminated food or fish and through inhalation [2] [9].

The main goal of this paper is to determine the levels/concentration of trace metals introduced into the environment as a result of the small scale mining activities and to compare the values with that of the Romanian guideline which are being used by the Ghana Environmental Protection Agency as a standard to determine if it has reached pollution levels. It will also provide evidences whether the mining activities actually introduced the trace metals into the environment. Lastly, this will help to determine situation and suggest appropriate environmental strategies to contain the problem coupled with recommendations to control the problem.

\section{Materials and Methods}

\subsection{Study Area and Location of Sampling Sites}

The study was conducted in Dunkwa-on-Offin in the Dunkwa District in the Central Region of Ghana. The District shares boarders with the Eastern and Ashanti Regions of Ghana. The samples investigated were soil and water collected from various parts of the study area. Fourteen (14) sampling sites were located (Tables 1-4). Sites 1 to 12 were located in farms within the vicinity of Dunkwa-on-Offin in various directions and distances from the centre of the town while site 13 was located in Nkronya, the main site of the small scale mining activities. Site 14 was located in the botanical gardens of the University of Cape Coast.

Table 1. Name and shortest distance of the sites 1 to 3 from the centre of the town (In South Direction of Nkronya).

\begin{tabular}{cc}
\hline Name of Village & Distance $(\mathrm{Km})$ \\
\hline Akyempem & 3.00 \\
Aduman & 10.00 \\
Kyekyewere & 12.50 \\
\hline
\end{tabular}

Table 2. Name and shortest distance of the sites 4 to 6 from the centre of the town (In North-Western Drection of Nkronya).

\begin{tabular}{cc}
\hline Name of Village & Distance $(\mathrm{Km})$ \\
Atekyem & 1.50 \\
Kwameprakrom & 6.40 \\
Ayemfori & 12.75 \\
\hline
\end{tabular}


Table 3. Name and shortest distance of the sites 7 to 9 from the centre of the town (In South-Western Direction of Nkronya).

\begin{tabular}{cc}
\hline Name of Village & Distance $(\mathrm{Km})$ \\
\hline Mfuom & 2.50 \\
Babiaraneha & 4.25 \\
Asikuma & 9.25 \\
\hline
\end{tabular}

Table 4. Name and shortest distance of the sites 10 to 12 from the centre of the town (In North-Western Direction of Nkronya).

\begin{tabular}{cc}
\hline Name of Village & Distance $(\mathrm{Km})$ \\
\hline Acquakrom & 1.00 \\
Tikyakrom & 2.25 \\
Manukrom & 5.50 \\
\hline
\end{tabular}

Ghana Environmental Protection Agency has adopted Romanian guideline on levels of trace metals in water and in soil as a standard to determine if the determined levels have reached pollution stage [10].

\subsection{Sample Collection and Analysis}

The water and soil samples were randomly collected from 14 sampling sites in 14 different areas within Dunkwa and the University of Cape Coast in the Central Region of Ghana. The sampling sites were located in various directions and distances from the centre of the town.

At each soil sample collection site, the samples were collected to cover the plough zone. The samples were collected by removing the top litter first and with a Teflon-coated soil auger; the sample was collected into an already well washed plastic containers and sealed. They were then conveyed to the laboratory for analysis.

For the water, samples were collected at each site from the river which runs through all the towns selected in the Dunkwa District. The sample bottles were rinsed with deionised water twice before samples were collected. Collected samples were then preserved with $0.5 \mathrm{ml}$ of concentrated nitric acid and stored in an ice chest with a temperature of $4^{\circ} \mathrm{C}$.

The samples were then analysed for the various trace metals. Atomic absorption spectrophotometer was employed in the analysis of the selected metals, $\mathrm{Hg}, \mathrm{Pb}$ and $\mathrm{Cu}$. The cold vapour technique was used for $\mathrm{Hg}$ determination while in the determination of $\mathrm{Pb}$ and $\mathrm{Cu}$, the flame-AAS technique was used [11] [12].

\section{Results and Discussions}

Although there are clear guidelines of limit values for maximum metal concentrations in drinking water, air and food, there is still no equivalent consensus of permissible levels of metals in rivers, sediments and soils by the Ghana Environmental Protection Agency. This is as a result of uncertainties of metal does-relationships in soil and sediments and hence some contradictory values.

The results were compared with similar studies conducted in Romani with similar characteristics. The WHO guideline values for drinking water and that of US for soil and sediments were also used for comparison [13].

The total metal concentrations recorded in this study clearly indicate that the situation of metal pollution within the study area where this small scale gold mining is taking place has reached intervention levels. The concentrations of Mercury in particular were identified and discussed because of its immediate implications on human health.

\subsection{Heavy Metal Pollution in Soil}

The 3 metals were detected in the soil sample at varying concentrations in all the selected towns. Table 5 shows the mean concentrations of the trace metals that were found in the soil sample. The pollutant concentration of $\mathrm{Cu}$ and $\mathrm{Pb}$ were measured in $\mathrm{mg} / \mathrm{Kg}$ while that of $\mathrm{Hg}$ was in $\mu \mathrm{g} / \mathrm{Kg}$. 
Table 5. Distribution of heavy metal concentrations in the soil sample.

\begin{tabular}{|c|c|c|c|c|c|c|c|}
\hline \multirow[t]{2}{*}{ Town } & \multirow[t]{2}{*}{ Distance from Nkronya (Km) } & \multicolumn{3}{|c|}{$\mathrm{mg} \mathrm{Pb} / \mathrm{Kg}$} & \multicolumn{2}{|c|}{$\mathrm{mg} \mathrm{Cu} / \mathrm{Kg}$} & \multirow{2}{*}{$\begin{array}{c}\mu \mathrm{g} \mathrm{Hg} / \mathrm{Kg} \\
\text { Std. D }\end{array}$} \\
\hline & & Mean & Std. D & Mean & Std. D & Mean & \\
\hline Kyekyewere & 3.00 & 99.80 & 9.30 & 51.60 & 0.10 & 261.50 & 13.05 \\
\hline Aduman & 10.00 & 63.40 & 0.70 & 64.30 & 0.10 & 137.50 & 5.15 \\
\hline Akyempem & 12.50 & 86.20 & 0.60 & 45.70 & 0.15 & 248.20 & 11.90 \\
\hline Atekyem & 1.50 & 30.40 & 0.25 & 85.40 & 0.20 & 148.20 & 0.60 \\
\hline Kwameprakrom & 6.40 & 89.40 & 8.85 & 49.90 & 0.10 & 133.70 & 9.85 \\
\hline Ayamfori & 12.75 & 132.00 & 0.45 & 71.40 & 0.15 & 146.90 & 5.15 \\
\hline Mfuom & 2.50 & 58.10 & 10.15 & 72.80 & 0.05 & 83.30 & 5.85 \\
\hline Babiaraneha & 4.25 & 82.40 & 3.10 & 59.90 & 0.20 & 74.00 & 13.85 \\
\hline Asikuma & 9.50 & 76.46 & 2.20 & 66.10 & 0.55 & 69.80 & 1.25 \\
\hline Acquahkrom & 1.00 & 25.00 & 2.35 & 66.10 & 0.44 & 116.90 & 10.00 \\
\hline Tikyakrom & 2.25 & 86.20 & 2.70 & 52.10 & 0.07 & 110.50 & 9.35 \\
\hline Manukrom & 5.50 & 46.10 & 3.65 & 38.10 & 0.06 & 136.20 & 6.15 \\
\hline Nkronya & 0.00 & 154.00 & 0.25 & 90.40 & 0.05 & 265.70 & 3.80 \\
\hline UCC & 275.00 & 6.20 & 0.00 & 3.10 & 0.00 & 1.10 & 0.00 \\
\hline Standard & & 80.00 & & 50.00 & & 40.00 & \\
\hline
\end{tabular}

From Figure 1, the lead concentrations in the various towns depicted a varying trend. About 50\% of the towns showed values less than the standard. The towns which showed the higher value concentration were towns where there has been extensive cultivation of cocoa and other similar food crops. Here, there has been profilic use of various pesticides, herbicides and artificial fertizers to boost crop yeilds. This could cause the increase of the metal in the soil.

The concentration of copper as seen in Figure 2 demonstrated the higher concentration of the metal. This could have come about as a reuslt of the area ever housing a copper mine dating back to 1493 - 1600 [14].

The total mercury concentrations were higher in all the towns as shown in Figure 3. There has been increased illegal mining activities across the entire district and with corresponding increase in mercury in the environment. This really suggests that the small scale gold mining and recovery activities contribute to the level of mercury. Comparing this results to that obtained on the sample from the botanical garden of the University of Cape Coast and that of an organized gold mine in Obuasi [15], the illegal mining indeed caused the pollution of the environment with the trace metals.

\subsection{Heavy Metal Pollution in Water Sample}

The heavy metals were detected in the water sample at varying concentrations in all the towns. Table 6 shows the mean concentrations of the trace metals in the water sample. The pollutant concentration of $\mathrm{Cu}$ and $\mathrm{Pb}$ were measured in $\mathrm{mg} / \mathrm{L}$ while that of $\mathrm{Hg}$ was in $\mu \mathrm{g} / \mathrm{L}$.

From Figures 4-6, the mean trace metal concentrations depicted a varying trend from the different towns. However, one thing has been observed that the concentrations were well above the standard level. The highest levels were recorded in towns that are located upstream of the river Offin which run through all the towns under study. Most of the concentrations reduced with stretch of the water flow down the stream. The river Offin which runs through Dunkwa district is up stream of its source in Tarkwa in the Western Region of Ghana which is well known for its gold mining activities as far back as 1471 [14]. The trace metal concentration however, confirmed the idea that heavy metal pollutants and others in water turn to reduce along the distance of travel for the moving surface of a water body [8] [16] [17]. 


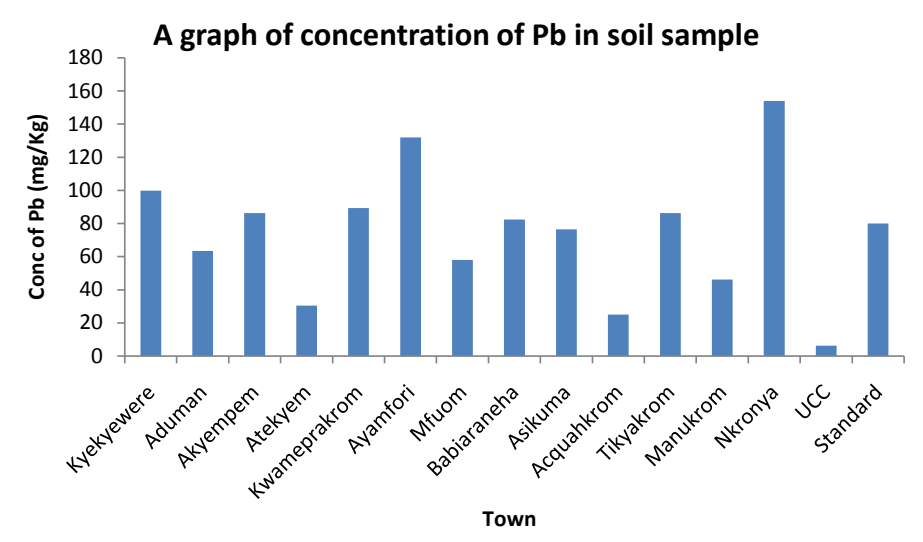

Figure 1. A graph showing the distribution of $\mathrm{Pb}$ concentrations in the soil sample at the various towns.

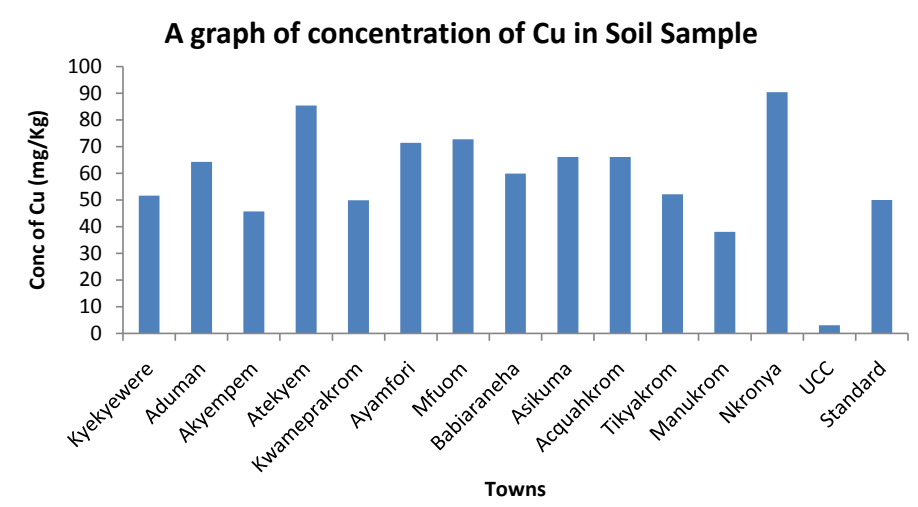

Figure 2. A graph showing the distribution of $\mathrm{Cu}$ concentrations in the soil sample at the various towns.

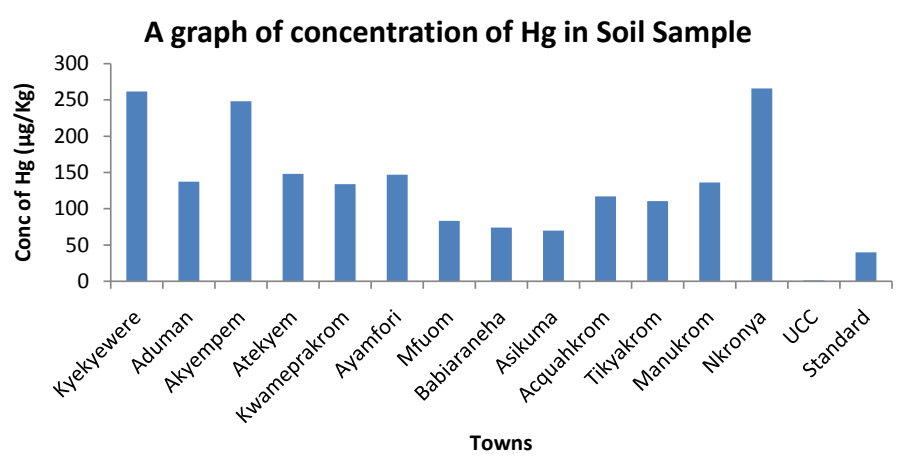

Figure 3. A graph showing the distribution of $\mathrm{Hg}$ concentrations in the soil sample at the various towns.

The results obtained from the sample taken from the botanical garden of the University of Cape Coast were expected because there is no mining activity taking place in the garden or even within the environs of the University. The presence of some trace metals as seen could be due largely to background levels in the soil and water as a result of the use of fertilizers and also carried by wind from elsewhere.

\section{Strategies and Recommendation}

\subsection{Strategies for Environmental Control}

The government, the civil society and nongovernmental organizations in Ghana have formed a joint public initi- 


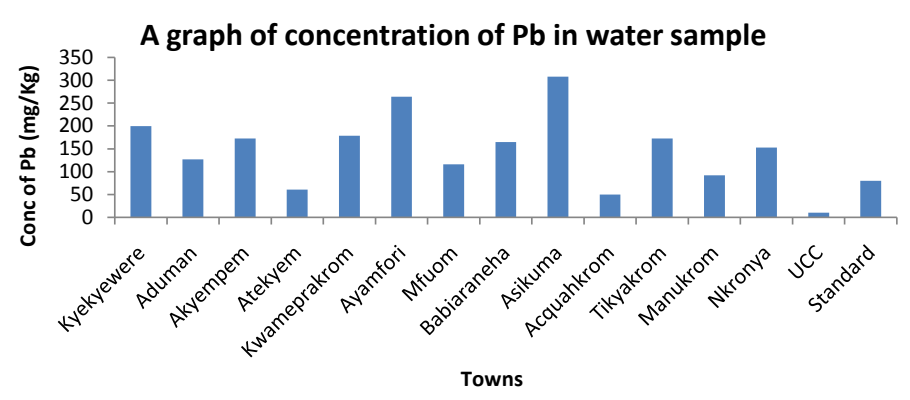

Figure 4. A graph showing the distribution of $\mathrm{Pb}$ concentrations in the water sample at the various towns.

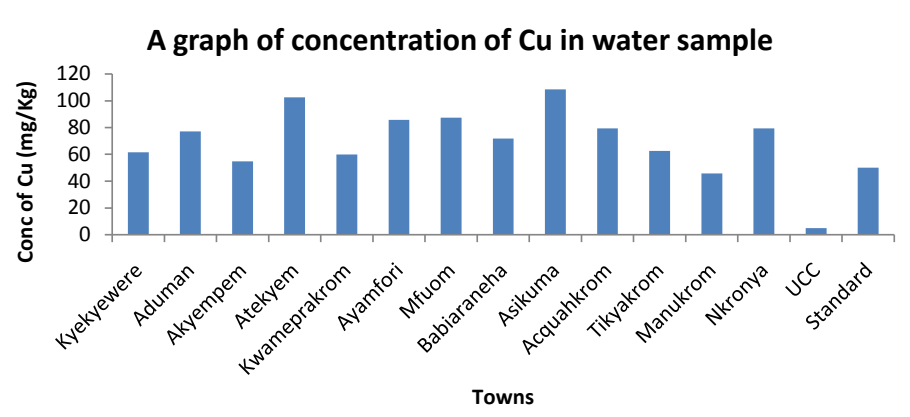

Figure 5. A graph showing the distribution of $\mathrm{Cu}$ concentrations in the water sample at the various towns.

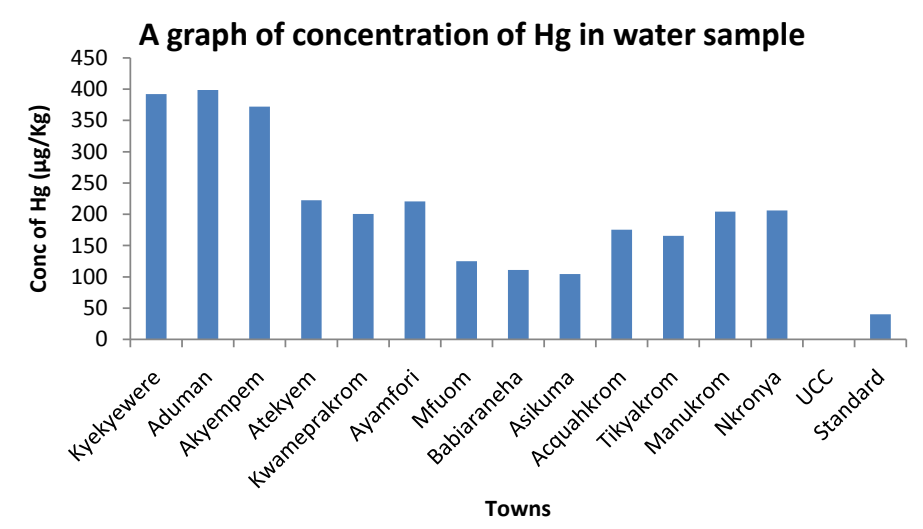

Figure 6. A graph showing the distribution of $\mathrm{Hg}$ concentrations in the water sample at the various towns.

ative to control the environmental pollution caused by small scale mining. These strategies should entail a joint initiative of the small scale miners, the government, civil societies, non-governmental organizations, and finally environmental entities and experts.

Revising environmental laws to ensure that they are relevant to the situation at hand, the laws should recognize and prescribe the best mining practices that promote environmental conservation.

Implementation of strong rules and regulations that are aimed at controlling the activities of the small scale gold miners; the regulations should provide for punishment and penalties for those who are found culpable.

Small scale miners should be encouraged to avoid sluicing of gold in the open air, rivers beds and streams. The small scale miners should avoid burning the gold amalgam in the open air as this releases dangerous fumes of mercury and carbon dioxide.

The government should implement land reclamation program. The initiative should entail planting of more trees on the areas that have undergone deforestation. Planting of more trees ensures that the soil regains its fertility and also reduces soil erosion. 
Table 6. Distribution of heavy metal concentrations in the water sample.

\begin{tabular}{|c|c|c|c|c|c|c|c|}
\hline Town & Distance from Nkronya (Km) & & $\mathrm{mg} \mathrm{Pb} / \mathrm{L}$ & & $\mathrm{mg} \mathrm{Cu} / \mathrm{L}$ & & $\mu \mathrm{g} \mathrm{Hg} / \mathrm{L}$ \\
\hline & & Mean & Std. D & Mean & Std. D & Mean & Std. D \\
\hline Kyekyewere & 3.00 & 199.60 & 9.30 & 61.60 & 0.10 & 392.25 & 10.44 \\
\hline Aduman & 10.00 & 126.80 & 0.70 & 77.16 & 0.10 & 398.55 & 4.12 \\
\hline Akyempem & 12.50 & 172.40 & 0.60 & 54.84 & 0.15 & 372.30 & 9.52 \\
\hline Atekyem & 1.50 & 60.80 & 0.25 & 102.48 & 0.20 & 222.30 & 0.48 \\
\hline Kwameprakrom & 6.40 & 178.80 & 8.85 & 59.88 & 0.10 & 200.55 & 7.88 \\
\hline Ayamfori & 12.75 & 264.00 & 0.45 & 85.68 & 0.15 & 220.35 & 4.12 \\
\hline Mfuom & 2.50 & 116.20 & 10.15 & 87.36 & 0.05 & 124.95 & 4.68 \\
\hline Babiaraneha & 4.25 & 164.80 & 3.10 & 71.88 & 0.20 & 111.00 & 11.08 \\
\hline Asikuma & 9.50 & 308.00 & 2.20 & 108.48 & 0.55 & 104.70 & 1.00 \\
\hline Acquahkrom & 1.00 & 50.00 & 2.35 & 79.32 & 0.44 & 175.35 & 8.00 \\
\hline Tikyakrom & 2.25 & 172.40 & 2.70 & 62.52 & 0.07 & 165.75 & 7.48 \\
\hline Manukrom & 5.50 & 92.20 & 3.65 & 45.72 & 0.06 & 204.30 & 4.92 \\
\hline Nkronya & 0.00 & 152.92 & 0.25 & 79.32 & 0.05 & 206.25 & 3.04 \\
\hline UCC & 275.00 & 10.00 & 0.01 & 5.00 & 0.00 & 0.02 & 0.00 \\
\hline Standard & & 80.00 & & 50.00 & & 40.00 & \\
\hline
\end{tabular}

The miners should be encouraged to avoid land excavation by using modern techniques and tools in mining.

\subsection{Recommendations}

To control environmental pollution caused by the activities of the small scale gold miners, this research therefore proposes the following recommendations.

The government should empower the Minerals commission to exercise its mandate through adequate funding and support.

The commission should enact legislations to control the small scale mining in the country.

The Minerals commission should conduct a proper and comprehensive research to determine the level of environmental degradation caused by the activities of the small scale miners.

The players in the industry both small scale and large scale operators should adopt proper environmental management tools.

The commission should control illegal mining activities practiced by the small scale miners. The government should enable the licensed small scale operators in the mining sector access funding from financial institutions in the economy. Funding of their operations will enable them to adopt modern mining techniques and abandon traditional techniques such as shallow alluvial mining which leads to the massive deforestation and excavation of the earth surface. Funding will also enable the miners to procure modern mining tools which can enable them crush hard rocks containing gold without causing noise and dust.

The government, the Minerals Commission, the civil society, and non-governmental organizations should conduct proper campaigns to enhance awareness on the impacts of environmental pollution. The initiative should aim at educating the small scale miners on the impacts of their activities.

\section{Conclusion}

The study revealed that small scale mining activities indeed introduce mercury and other trace metal pollutants into the environment. The concentrations of these trace metals determined in this study showed that it has 
reached pollution levels in the environment and therefore need urgent attention. This is because the results as compared to the standards and other areas where organized gold mining has taken place indicated much higher concentrations of the selected trace metals.

\section{References}

[1] Agyemang, I. (2010) Population Dynamics and Health Hazards of Small Scale Mining Activity in the Bolgatanga and Talensi-Nabdam Districts of the Upper East Region of Ghana. Indian Journal of Science and Technology, 3.

[2] Cobbina, S.J., Myilla, M. and Michael, K. (2013) Small Scale Gold Mining and Heavy Metal Pollution: Assessment of Drinking Water Sources in Datuku in the Talensi-Nabdam District. International Journal of Scientific \& Technology Research, 2, 96.

[3] Manu, A., Twumasi, Y.A. and Coleman, T.L. (2004) Application of Remote Sensing and GIS Technologies to Assess the Impact of Surface Mining at Tarkwa, Ghana. Geoscience and Remote Sensing Symposium, IGARSS'04 Proceedings. IEEE Intrnational, 1, 572-574.

[4] Obiri, S. (2007) Determination of Heavy Metals in Boreholes in Dumasi in the Wassa West. District of Western Region of the Republic of Ghana. Environmental Monitoring and Assessment, 130, 455-463.

[5] Tom-Dery, D., Dagben, Z.J. and Cobbina, S.J. (2012) Effect of Illegal Small Scale Mining Operations on Vegaetation Cover of Arid Northern Ghana. Research Journal of Environmental and Earth Sciences, 4, 674-679.

[6] Appiah, H. (1998) Organization of Small Scale Gold Mining Activities in Ghana. Journal of the South African Institute of Mining and Metallurgy, November 1998.

[7] Tetteh, S., Golow, A.A., Essumang, D.K. and Zugle, R. (2010) Levels of Mercury, Cadmium and Zinc in the Topsoil of Some Selected Towns in the Wassa West District of the Western Region of Ghana. Soil and Sediment Contamination: An International Journal, 19, 635-643.

[8] Ezeh (2007) Environmental Significance of Heavy Metals Distribution. Ebonyi River Drainage System, Abakaliki and Ohaozara Areas, South Eastern Nigeria. Ph.D. Thesis, Nnamdi Azikiwe University, Awka.

[9] Nartey, V.K., Klate, R.K., Hayford, E.K., Doamekpor, L.K. and Appoh, R.K. (2011) Assessment of Mercury Pollution in Rivers and Streams around Artisanal Gold Mining Areas of the Birim North District of Ghana. Journal of Environmental Protection, 2, 1227-1239.

[10] Olade (2009) Dispersion of Cd, Pb and Zn in Soils and Sediments of a Humid Tropical Ecosystem in Nigeria. In: Hutchinson, T.C., Ed., Lead, Mercury, Cadmium and Arsenic in the Environment, John Wiley and Sons, New York.

[11] Office of Research and Development, US Environmental Protection Agency (1991) Methods for the Determination of Metals in Environmental Samples. Office of Research and Development, US Environmental Protection Agency, Cincinnati, 293.

[12] Perkin-Elmer (1993) Analytical Methods for Atomic Absorption Spectrophotometry. Norwalk, Connecticut.

[13] WHO (2006) Guidelines for Drinking Water Quality. 4th Edition, World Health Organization, Geneva.

[14] Hug, M.M. (1989) The Economy of Ghana: The First 25 Years Since Independence. Macmillian Press Ltd., London, 153-155.

[15] Akabzaa, T.M., Banoeng-Yakubo, B.K. and Seyire, J.S. (2005) Impact of Mining Activities on Water in the Vicinity of the Obuasi Mine. 79, 377-379.

[16] Ezeh, H.N. and Chukwu, E.A. ( 2011) Small Scale Mining and Heavy Metals Pollution of Agricultural Soils: The Case of Ishiagu Mining District, South Eastern Nigeria. Journal of Geology and Mining Research, 3, 87-104.

[17] Kpan, J.D.A. (2008) Studies on Levels of Mercury, Zinc and Cadmium in Soils in the Vicinity of an Alluvial Goldmine at Dunkwa-on-Offin. Unpublished Thesis, University of Cape Coast, Cape Coast. 